\title{
The use of Senilia senilis seashells as a substitute for coarse aggregate in eco-friendly concrete
}

\author{
Gideon O. Bamigboye ", Odochi Okara, Daniel E. Bassey, Kayode J. Jolayemi, David Ajimalofin \\ Department of Civil Engineering, Covenant University, Ota, Ogun State, Nigeria
}

\section{A R T I C L E I N F O}

\section{Keywords:}

Sustainable materials

Compressive strength

Building materials

Concrete

Seashells

Cement

\begin{abstract}
A B S T R A C T
This research appraised the effects of recycling senilia senilis waste seashells as a full or partial substitution for natural coarse aggregate (granite) in eco-friendly concrete production. The design mix employed a 1:2:4 concrete mix ratio for M25 grade, a w/c ratio of 0.5 , river sand as fine aggregate, ordinary Portland cement (OPC) as a binder, and varying proportions of crushed seashells and granite as coarse aggregates (0:100, 10:90, 20:80, $30: 70,40: 60$, and 50:50). Laboratory tests revealed that workability requirements were only met with a $10 \%-$ $40 \%$ seashell addition, workability decreased with increasing seashell percentages. The compressive strength increased with curing age but decreased with the additions of seashells. The seashell-modified mixes failed to reach the design target strength for M25 concrete. Nonetheless, the 10 and $20 \%$ seashell-modified mixes achieved the required strength for M20 concrete. Split tensile strength increased with curing age for all mixes, the seashell-modified mixes yielded slightly reduced tensile strength values compared to the unmodified mix at all curing stages. However, the $10 \%, 30 \%$, and $40 \%$ seashell-modified batches attained recommended split tensile strength values on the 28th day. Furthermore, high correlations were observed between the datasets of the some of the measured parameters, and variations for Split tensile strength as a function of seashell percentage and compressive strength were developed discretely by fitting the experimental data to the numerical models. Relationships were also developed for compressive strength and workability as functions of seashell percentage. Eco-friendly building construction recycling waste seashells is encouraged as it offers positive economic and environmental prospects.
\end{abstract}

\section{Introduction}

\subsection{Eco-friendly concrete production and the recycling}

With the rising concern for the conservation of non-renewable natural resources and control of global pollution comes the notion of ecofriendly concrete production. Eco-friendly concrete production incorporates eco-mining, eco-design, eco-production, eco-construction, and eco-maintenance for socio-economic development [1,2]. Succinctly, eco-friendly construction is a practice that is advantageous or non-degrading to the environment, and is resource and energy-efficient. The construction design must provide for waste utilization, while minimizing negative environmental impacts. Eco-mining entails minimized extraction and minimal usage of natural aggregates. Eco-production means processing and manufacturing of building construction materials must be done at reduced temperatures, to ensure minimal emission of air pollutants and reduced energy consumption.
Eco construction ensures that eco-friendly recycled materials improve ease-of-construction operations, saves construction time and cost requirements, guarantees the safety of workers and final users, and reduces vibrations, noise, and other pollution that occur during construction [1]. Eco-maintenance entails utilizing recycled materials in renovation and rehabilitation of building structures to ensure the sustainable extension of design life. Socioeconomic development ensures a participatory and collective strategy through sharing research outcomes and best practices that lead to the socio-economic empowerment of stakeholders in local communities via trainings, and their inclusion in the stages of design and construction [3,4]. It can be viewed as the response of private and public stakeholders in both developed and developing countries to the present trend of sustainable construction of eco-cities [5]. The scarcity and high demand for natural materials, high costs of energy for extraction, and increasing restrictions and costs for landfilling have also been principal to the search for eco-friendly alternatives [6-8].

\footnotetext{
* Corresponding author.

E-mail address: gideon.bamigboye@covenantuniversity.edu.ng (G.O. Bamigboye).
} 
The US Environmental Protection Agency (USEPA) reported some of the benefits of this eco-friendly production practice including; reductions in material haulage and disposal costs, increased design life and capacity of landfills, and in some cases, relatively lower material costs compared to virgin materials [9]. It can also help in greening our community infrastructures by reducing the expulsion of greenhouse gases, eyesores and air pollution, and contamination of groundwater, while supporting conservation [10-13]. Consequently, secondary industries utilizing these wastes in the production of eco-friendly composites for construction, have sprung up in the past few decades. Hence, recording reductions in the requirements and consumption of natural materials, and improved environmental protection [14,15].

Challenges to eco-friendly concrete production include concerns on variations in these wastes, discrepancies in physical and chemical composition of the wastes, insufficient data on the characteristics of the manufactured eco-friendly products, and low public awareness on the importance and necessary measures to promote recycling, hence, ecofriendly concreting [16]. Other obstacles encountered include the cost of labour, lack of government policy to support practice, and well-limited practical application of eco-friendly practices in real-life projects to allow for long-term cost and performance evaluations [17-20].

From previous studies, it is apparent that recycled wastes can act as substitutes for cementitious binders, fine aggregates, coarse aggregates, and in some cases, admixtures depending on the waste's properties and the desired utilization. Sustainable materials utilized in eco-friendly construction include steel slag, fly ash, reclaimed concrete and asphalts, high- and low-density waste plastics, waste rubber tires, asphalt shingles, mine tailings, various agricultural wastes, and aquaculture wastes such as seashells, to list a few [21-24]. To facilitate the practice of eco-friendly construction and maintenance generally, and in green building construction, in particular, the need for stakeholder extensive participation and interaction especially with key decision-makers at organization level was identified as a paramount factor [25-27]. Hence the optimal blend of locally-sourced and non-locally-sourced recycled aggregates is recommended to support conservation [28,29].

To promote the practice, the USA, Denmark, India, and the Netherlands are examples of countries that have provided regulatory policies to prioritize the recycling of waste materials in the production of eco-friendly composites in the construction industry [1,6]. Some of these recycled wastes have been proven effective in the construction of low-to mid-strength composites especially in rural settlements [30,31].

\subsection{Production of bivalvia molluscs shellfish and waste seashells}

Bivalvia mollusc (herein referred to as mollusc or shellfish) production shares a major sector of the global aqua-cultural industry. As of 2016 , molluscs production accounted for about 15 million tonnes (23\%) of the aquaculture industry's total annual production [32]. In 2018, total molluscs production increased to over 16.1 million tonnes. Indicating an increase of about $6.8 \%$ in just two years [33]. There are certain regions around the world with high prevalence in molluscs aquaculture. China in particular, and Eastern Asia as a whole, dominates in the production of molluscs by live weight. However, the Western European region, the USA, and Chile also yield significant [32,34,35]. The distribution of mollusc production (which includes clams, conchs, abalones, cockles, fresh-water gastropods, mussels, fresh-water mussels, oysters, winkles, and scallops) among the top ten producing nations is illustrated in percentages in Fig. 1.

The key concern in shellfish production that hinders its continued sustainability is the issue of shell wastes. Shell waste management are in many cases, a big challenge for shellfish producers, marketers, and consumers. Depending on species, shells may account for up to $75 \%$ of the organism's total weight [36]. As such, a vast proportion of its production is classified as an environmental nuisance. Unregulated and indiscriminate disposal procedures can lead to massive heaps of

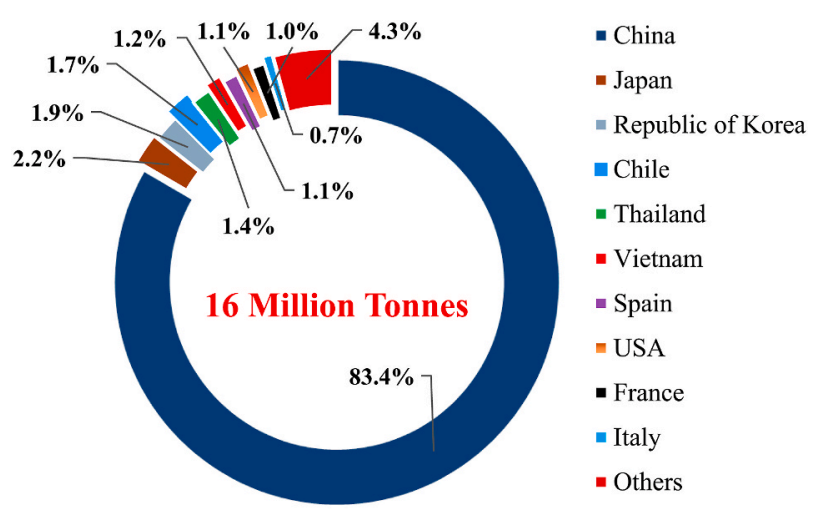

Fig. 1. The distribution of mollusc production among the top ten producing nations (2018) (Source $[37,38]$ ).

seashells in open lands across the globe, creating strong odours, eyesores, and contaminating air, soil, surface water, and groundwater quality if left uncontrolled [37].

An evaluation of the quantity of waste seashells with capacity for use as aggregates in eco-friendly concreting in the UK indicates about 43,000 tonnes per year [39]. The cockleshell specie, of which senilia senilis shell shares major similarities, accounts for $47 \%$ of this. The percentage distribution across seashell type is shown in Fig. 2. Some of these seashells, especially cockles, possess a high composition of calcium carbonates $\left(\mathrm{CaCO}_{3}\right)$, which is prominent in limestones. However, limestone, a heavily exploited natural resource, is continuously mined massively worldwide as ground calcium carbonate for a range of applications, including cement production [37].

\subsubsection{Shellfish production in Nigeria}

Nigeria with total land and water area of 910,000 and $13000 \mathrm{~km}^{2}$, respectively, possesses a coastline span of $853 \mathrm{~km}$ bordering the Atlantic Ocean through the Gulf of Guinea. The coastline is indented in the west with a lagoon system, and in the south (Niger-Delta region) with a widespread mangrove swamp and a delta complex opening into the ocean via rivers including Opobo, Bonny, Escravos, Forcados, Dodo, Middleton, Fishtown, and Benin [40].

Nine out of the thirty-six states are located in the coastal region, stretching inland for around $15 \mathrm{~km}$ in Lagos, to nearly $150 \mathrm{~km}$ in the Niger delta, as shown in Fig. 3. Shellfishes found in the inshore and offshore waters of Nigeria include molluscs (gastropods, bivalves, and univalves), crustaceans (shrimps, prawns, crabs, and lobsters) [41]. The growth trend of the total annual fishery capture and aquaculture data for Nigeria, of which nearly 30\% include shellfishes, between 1980 and 2017 are presented in Fig. 4.

The increasing rate of production has consequentially led to increased generation of waste shells. Shells such as periwinkle have in the past years been used by locals for minor constructions in the NigerDelta regions [42-44], while a majority is continuously accrued and abandoned in open lands, constituting in environmental pollution.

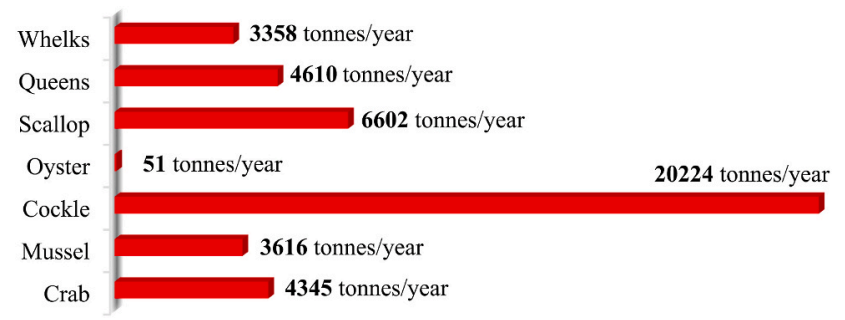

Fig. 2. Estimated quantity of annual waste seashell generation in the UK as of 2017 (Source [39]). 


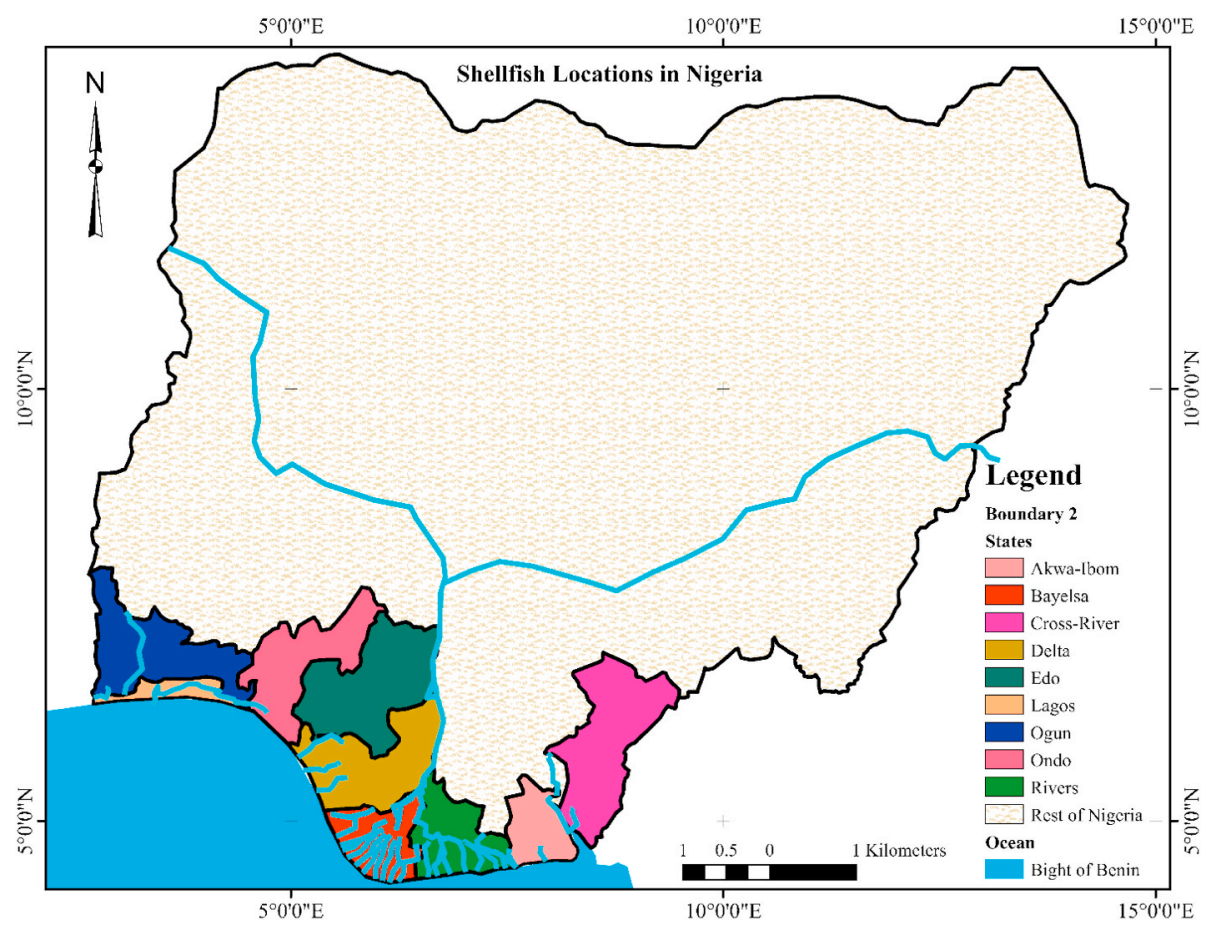

Fig. 3. Coastal states with prevailing shellfish aquaculture and waste seashells in Nigeria.

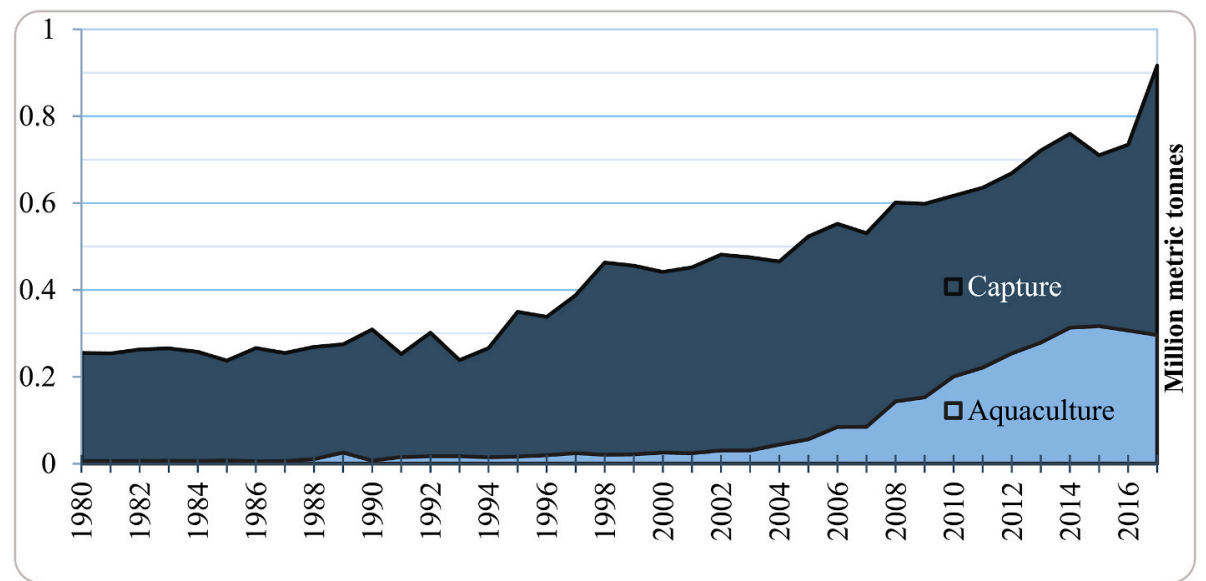

Fig. 4. Annual Aquaculture production in Nigeria (1980-2017) (Source: FAO [45]).

\subsubsection{Senilia senilis}

Senilia senilis is an edible specie of the saltwater shellfish, it is a marine bivalve mollusc in the family Arcidae (the ark shells). Its shells can be found on or underneath the soils around seashores. In Africa, it lives covered in silty sands of waterfronts, tidal ponds, and channels, from Western Sahara to Angola. This species have vigorously been harvested in the past several decades, and its shell middens are massive over the West African shores [46]. Fig. 5 shows the scientific classification of the senilia senilis seashells based on hierarchy.

\subsection{Research objectives}

This article is aimed at proffering an eco-friendly approach for recycling waste senilia senilis seashells as a replacement for coarse aggregates in the production of cement concrete for use in building construction. The workability and strength performance of seashellmodified concrete composites were appraised through the required tests. Furthermore, relationships between the quantity of seashell and the workability and strength parameters were developed to aid prediction. It is anticipated that the research outcomes will offer a suitable alternative material for eco-friendly concrete production.

\section{Literature review on seashell utilization in concrete}

Several studies have been done to assess the effects of using different kinds of seashells as a replacement for cement, fine aggregate (FA), and coarse aggregates (CA) [48-52]. The high composition of $\mathrm{CaCO}_{3}$ present in these seashells make them suitable for consideration in increasing the strength and bulk unit weight of concrete [53]. Waste seashells have also been used in self-compacting and pervious concrete [54]. A majority of these studies recorded decreases in at least one among the compressive, flexural, or split tensile strength properties, upon seashell addition, when compared to conventional concrete. However, optimal seashell-modification blends still offered required strength performance based on relevant standards, and were recommended as suitable. Table 1 presents the outcomes of some past studies on the effect of seashells on 


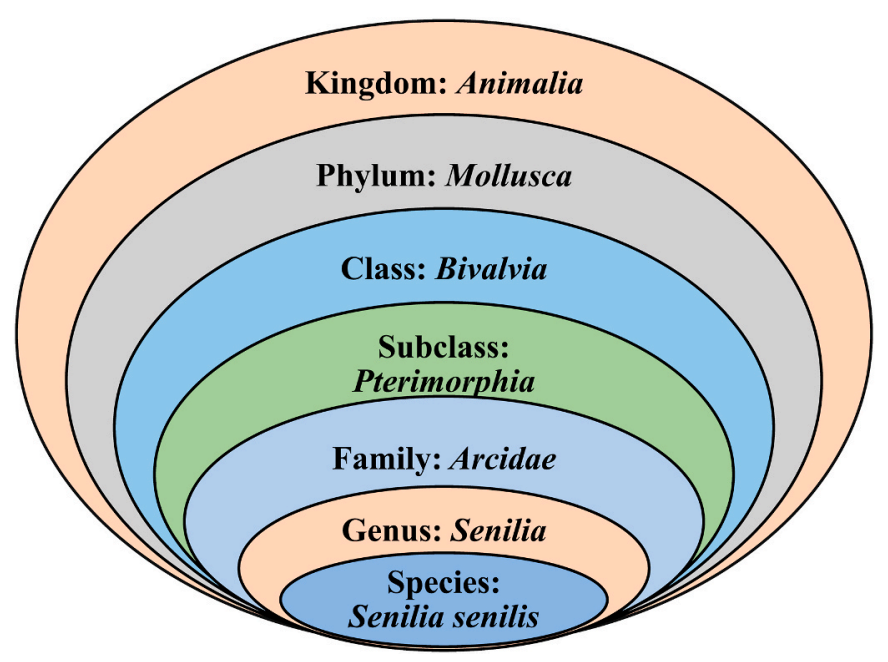

Fig. 5. Scientific hierarchical classification of Senilia senilis (Source [47]).

compressive strength, split tensile strength, and setting time of concrete. This study extensively expounds the notion of eco-friendly concrete production, highlighting the current challenges faced in its practical application, and the advantages attainable from its adoption.

\section{Materials and methods}

All methodologies adopted in the preparation, mixing, and testing of the concrete samples in this study, were based on relevant standards. The classification, workability, and strength features of seashellmodified concrete were analysed and compared to conventional concrete, past outcomes, and statutory limits.

\subsection{Materials}

The materials used in this study were sourced locally, and are listed below;

i. Grade 42.5 N Dangote brand of ordinary Portland cement was used with potable water as a binder. The chemical composition is shown in Table 2.

ii. Senilia senilis seashells shown in Fig. 6 were crushed and used in percentages as replacements for coarse aggregate. The seashells were harvested from Seme border shores of South-western Nigeria. Its chemical composition is presented in Table 2.

iii. Fine river sand was collected from the shores of River Ogun, Abeokuta, Ogun State, Nigeria, and used as fine aggregates.

iv. Granite collected from the Igbo-Ora quarry in Ogun State, Nigeria was used as natural coarse aggregates.

\subsection{Methodology}

The preparation of materials, mixing, batching, and laboratory tests were all carried out in the Civil Engineering Department's concrete laboratory, Covenant University, Ogun State, Nigeria.

\subsubsection{Mix design, sampling, and batching}

The seashells and natural aggregates were sampled, properly cleansed of impurities, air-dried, and then sieved to obtain maximum sizes shown in Table 3. The seashells were first crushed with the aid of a Los Angeles (LA) abrasion machine, before sieving. Table 3 presents the mix design adopted, showing the weightage of the constituent materials in each mixed batch studied.

Six sample batches were assessed in this study. An unmodified (control) batch of conventional concrete aggregates, and five seashellmodified batches designed combining granite and crushed seashells in

Table 1

Summary of some past research outcomes on seashell recycling in concrete.

\begin{tabular}{|c|c|c|c|c|c|c|c|}
\hline \multirow[t]{2}{*}{ Reference } & \multirow[t]{2}{*}{ Seashell type } & \multirow[t]{2}{*}{ Substituted material } & \multirow{2}{*}{$\begin{array}{l}\text { Percentages by weight, } \\
(* \text { Optimal) }\end{array}$} & \multicolumn{3}{|c|}{ Results compared to Conventional Mix } & \multirow[t]{2}{*}{ Remark } \\
\hline & & & & $\begin{array}{l}\text { Compressive } \\
\text { strength }\end{array}$ & $\begin{array}{l}\text { Split tensile } \\
\text { strength }\end{array}$ & $\begin{array}{l}\text { Setting } \\
\text { time }\end{array}$ & \\
\hline Olivia et al. [48] & $\begin{array}{l}\text { Cockle clam } \\
\text { Marsh clam }\end{array}$ & Cement & $* 4$ & $\begin{array}{l}\text { Decline } \\
\text { Increase }\end{array}$ & $\begin{array}{l}\text { Decline } \\
\text { Increase }\end{array}$ & $\begin{array}{l}\text { Slower } \\
\text { Faster }\end{array}$ & Suitable \\
\hline Tayeh et al. [49] & Clam & Cement & $5, * 10,15,20$ & Increase & Increase & - & Suitable at * \\
\hline Soneye et al. [55] & Periwinkle & FA and CA & $10, * 30,50,100$ & Decline & Decline & - & Suitable at * \\
\hline Olivia et al. [56] & Cockle clam & Cement & $* 2,4,6,8$ & Decline & Increase & - & Suitable at * \\
\hline $\begin{array}{l}\text { Mohanalakshmi et al. } \\
\text { [50] }\end{array}$ & $\begin{array}{l}\text { Combine- Mollusca, } \\
\text { lamella }\end{array}$ & FA & $20, * 40,60,80$ & Increase & Increase & - & Suitable at * \\
\hline $\begin{array}{l}\text { Nahushananda et al. } \\
\text { [57] }\end{array}$ & Varying & $\mathrm{CA}$ & $10, * 20,30,40$ & Increase & Increase & - & Suitable at * \\
\hline Varhen et al. [51] & Peruvian Scallop & FA & $5, * 20,40,60$ & Decline & Decline & Slower & Suitable at * \\
\hline Kumar et al. [58] & Cockle & $\mathrm{CA}$ & $10, * 20,30$ & Decline & Decline & - & Suitable at * \\
\hline $\begin{array}{l}\text { Martínez-García et al. } \\
\text { [52] }\end{array}$ & Mussels & $\begin{array}{l}\text { CA, FA, (CA + FA } \\
\text { combine) }\end{array}$ & $* 25,50,75,100(5, * 12.5)$ & Decline & Decline & - & Suitable at * \\
\hline Attah et al. [42] & Oyster shell & Cement & $* 5,10,15,20$ & Decline & - & - & Suitable at * \\
\hline Otunyo et al. [59] & Periwinkle & FA & $30, * 50,100$ & Decline & - & - & Suitable at * \\
\hline Inyang and Etuk [43] & $\begin{array}{l}\text { Oyster, periwinkle, } \\
\text { snail }\end{array}$ & Additive & Not specified & - & - & Faster & Suitable \\
\hline $\begin{array}{l}\text { Richardson and Fuller } \\
\text { [60] }\end{array}$ & Oyster & FA, CA & $\begin{array}{l}\text { FA: } * 10,50 \\
\text { CA: } * 10,50\end{array}$ & Decline & - & - & Suitable at * \\
\hline Norhazurina et al. [61] & Cockle & Cement & $* 5,10,15,25,50$ & Decline & - & Slower & Suitable at * \\
\hline Umoh and Ujene [44] & Periwinkle & Cement & 30 & Increase & Increase & - & Suitable \\
\hline Nguyen et al. [62] & $\begin{array}{l}\text { Crepidula } \\
\text { Scallop } \\
\text { Queen scallop }\end{array}$ & $\mathrm{CA}$ & $\begin{array}{l}60 \\
60 \\
60\end{array}$ & $\begin{array}{l}\text { Decline } \\
\text { Decline } \\
\text { Decline }\end{array}$ & $\begin{array}{l}\text { Decline } \\
\text { Decline } \\
\text { Decline }\end{array}$ & $\begin{array}{l}- \\
- \\
-\end{array}$ & $\begin{array}{l}\text { Suitable with } \\
\text { Scallop }\end{array}$ \\
\hline $\begin{array}{l}\text { Abinaya and Venkatesh } \\
\text { [63] }\end{array}$ & Oyster & Cement & $2.5, * 5,7.5,10,20$ & Increase & Increase & - & Suitable at * \\
\hline $\begin{array}{l}\text { Lertwattanaruk et al. } \\
\text { [64] }\end{array}$ & $\begin{array}{l}\text { Green mussel } \\
\text { Short clams } \\
\text { Cockle } \\
\text { Oyster }\end{array}$ & Cement in mortar & $\begin{array}{l}* 5,10,15,20 \\
* 5,10,15,20 \\
* 5,10,15,20 \\
* 5,10,15,20\end{array}$ & $\begin{array}{l}\text { Decline } \\
\text { Decline } \\
\text { Decline } \\
\text { Decline }\end{array}$ & $\begin{array}{l}- \\
- \\
-\end{array}$ & $\begin{array}{l}\text { Slower } \\
\text { Slower } \\
\text { Slower } \\
\text { Slower }\end{array}$ & Suitable at * \\
\hline Wang et al. [65] & Cockle & Cement & 78 & Increase & - & - & Suitable \\
\hline
\end{tabular}


Table 2

Typical Chemical composition of Cement and Senilia senilis seashells (Source [53,54].

\begin{tabular}{|c|c|c|c|c|c|c|c|c|c|c|}
\hline \multirow[t]{2}{*}{ Material } & \multicolumn{9}{|c|}{ Compounds and Percentages } & \multirow[b]{2}{*}{$\mathrm{K}_{2} \mathrm{O}+\mathrm{Na}_{2} \mathrm{O}$} \\
\hline & $\mathrm{SiO}_{2}$ & $\mathrm{Al}_{2} \mathrm{O}_{3}$ & $\mathrm{CaO}$ & $\mathrm{C}_{3} \mathrm{~S}$ & $\mathrm{C}_{2} \mathrm{~S}$ & $\mathrm{C}_{3} \mathrm{~A}$ & $\mathrm{C}_{4} \mathrm{AF}$ & $\mathrm{SO}_{3}$ & $\mathrm{Fe}_{2} \mathrm{O}_{3}$ & \\
\hline Cement & 20.71 & 5.45 & 60.4 & 58.45 & 18.59 & 6.38 & 13.59 & 2.37 & 3.63 & 0.88 \\
\hline \multirow[t]{2}{*}{ Seashell } & $\mathrm{CaCO}_{3}$ & $\mathrm{SiO}_{2}$ & $\mathrm{MgO}$ & $\mathrm{Al}_{2} \mathrm{O}_{3}$ & $\mathrm{Na}_{2} \mathrm{O}$ & $\mathrm{SO}_{3}$ & $\mathrm{SO}_{4}$ & $\mathrm{~K}_{2} \mathrm{O}$ & - & - \\
\hline & 97.13 & 0.98 & 0.02 & 0.17 & 0.37 & 0.13 & 0.7 & 0.03 & - & - \\
\hline
\end{tabular}

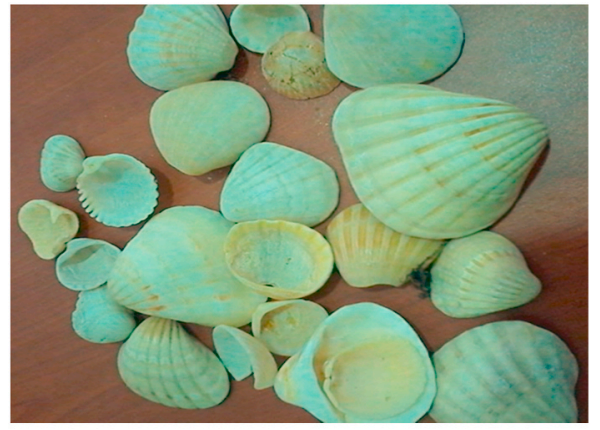

a) Before crushing

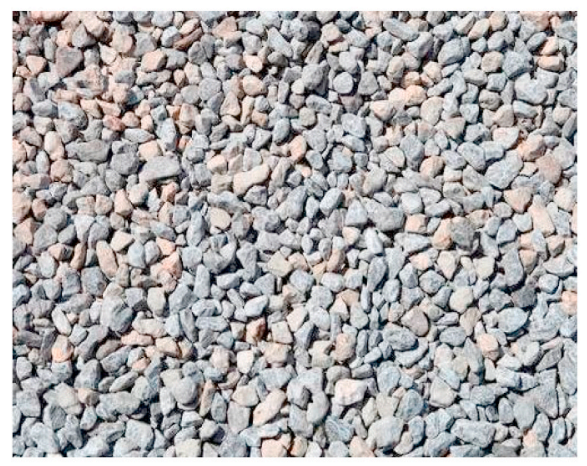

c) Granite sample

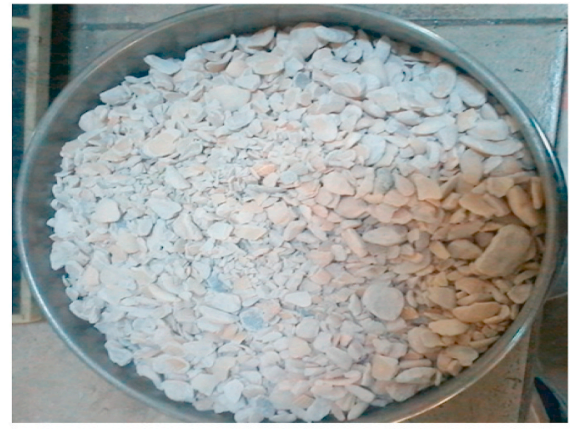

b) After crushing

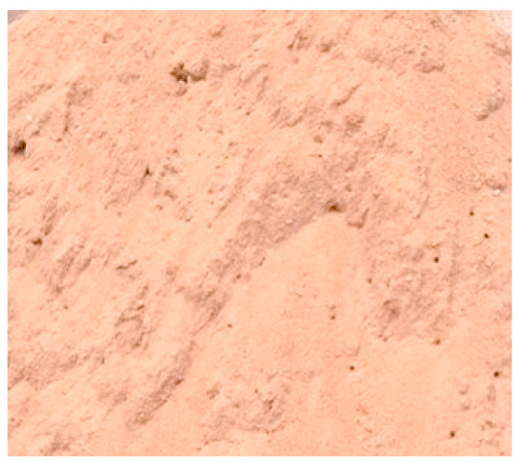

d) Fine aggregate

Fig. 6. [a] Senilia senilis (Before crushing) [b] Senilia senilis (After crushing) [c] Granite sample [e] Fine aggregates sample.

Table 3

Mix design adopted.

\begin{tabular}{llllll}
\hline \multirow{2}{*}{ Mixed Batch } & \multicolumn{5}{l}{ Material content $\left(\mathrm{kg} / \mathrm{m}^{3}\right)$} \\
\cline { 2 - 6 } & Water & Cement & River sand & Granite & Crushed senilia senilis \\
\hline SS-00 & 155 & 310 & 620 & 1240 & 0.00 \\
SS-10 & 155 & 310 & 620 & 1116 & 124 \\
SS-20 & 155 & 310 & 620 & 992 & 248 \\
SS-30 & 155 & 310 & 620 & 868 & 372 \\
SS-40 & 155 & 310 & 620 & 744 & 496 \\
SS-50 & 155 & 310 & 620 & 620 & 620 \\
\hline
\end{tabular}

varying ratios (100:0, 90:10, 80:20, 70:30, 60:40, and 50:50), as coarse aggregate. Concrete was cured by submerging in potable water. Fig. 7 illustrates the batching program adopted. The 1:2:4 concrete design mix ratio was adopted with a target mean strength $\left(f_{c u}\right)$ of $25 \mathrm{~N} / \mathrm{mm}^{2}$ for M25 grade concrete, and a fixed water/cement $(\mathrm{w} / \mathrm{c})$ ratio of 0.5 . Each mix batch comprised of three cylinder-shaped concrete $(200 \mathrm{~mm}$ in length and $50 \mathrm{~mm}$ in radius) for split tensile strength testing, and four cube-shaped concrete $(\mathrm{L}=\mathrm{B}=\mathrm{H}=100 \mathrm{~mm}$ ) for compressive strength testing as per ASTM C496/C496 M [66] and ASTM C39/C39 M [67], respectively.

\subsubsection{Tests conducted and standards}

The tests conducted in this study were grouped into three: the initial tests on materials (to evaluate the physicomechanical characteristics and suitability of each set of material), workability test (to assess the fluidity and consistency of each freshly-mixed batch), and the tests on hardened concrete (to measure the mechanical strength properties of each concrete batch). All tests were conducted following procedures as stated in relevant standards. Table 4 presents the standard requirements for aggregates and concrete.

\subsubsection{Initial tests on materials}

3.2.2.1.1. Particle size analysis. The particle size distribution of all three sets of aggregate material (river sand, crushed seashells, and granite), was assessed through sieve analysis, following IS 2386 [76]. Here, $1000 \mathrm{~g}$ of the sampled aggregate is poured into the largest-sized sieve, in a graduated set of test sieves. The sieves are then positioned and allowed to vibrate on an electro-mechanical sieve shaker. Computation of the weight of aggregate retained on each sieve was done to determine the distribution of particle sizes for the three material sets.

3.2.2.1.2. Specific gravity and water absorption. The specific gravity and water absorption of each aggregate set was determined using a pycnometer following ASTM D1429 [77]. The bulk densities were computed as the mass of sampled aggregate that fills the container, divided by the volume of the container. The water absorption, expressed 


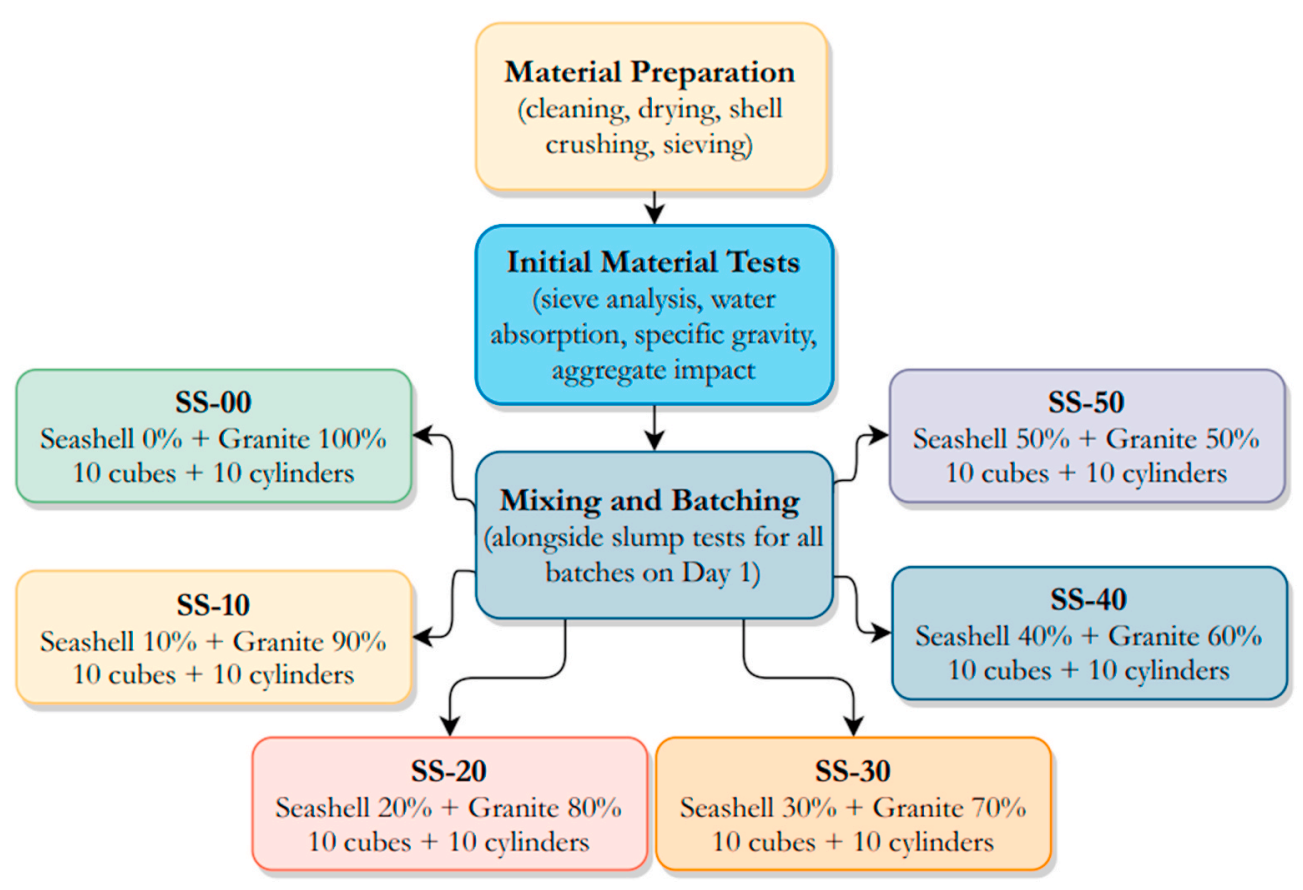

Fig. 7. Experimental program.

Table 4

Standard requirements for aggregates and concrete.

\begin{tabular}{lll}
\hline Reference Standard & Property & Requirement \\
\hline Fine aggregate & & \\
ASTM C33/C33 M [68] & Fineness modulus & $2.0-3.3$ \\
ASTM C127 [69] & Absorption (\%) & $<5$ \\
ASTM C127 [69] & Specific gravity & $2.4-3.0$ \\
ASTM C88/C88 M [70] & Soundness (\%) & $<15$ \\
Coarse aggregate & & \\
BS 812-110 [71] & Aggregate Impact value (\%) & $<30$ \\
ASTM C33/C33 M [68] & Nominal maximum size (mm) & $9.5-90$ \\
ASTM C131/C131 M [72] & Abrasion resistance (\%) & $<30$ \\
ASTM C128 [73] & Absorption (\%) & $<2$ \\
ASTM C128 [73] & Specific gravity & $2.5-2.9$ \\
Concrete & & $2240-2400$ \\
ASTM C138/C138 M [74] & Density (kg/m $\left.{ }^{3}\right)$ & $20-40$ \\
ASTM C39/C39 M [67] & Compressive strength $\left(\mathrm{N} / \mathrm{mm}^{2}\right)$ & $3-5$ \\
ASTM C293/C293 M [75] & Flexural strength $\left(\mathrm{N} / \mathrm{mm}^{2}\right)$ & $2-5$ \\
ASTM C496/C496 M [66] & Split tensile strength $\left(\mathrm{N} / \mathrm{mm}^{2}\right)$ & \\
\hline
\end{tabular}

in percentage, was calculated at the end of the procedure.

3.2.2.1.3. Aggregate impact value. Aggregate impact tests were conducted on the two coarse aggregate materials (crushed seashells and granite), following BS 812 [71]. Aggregate impact value (AIV) was determined by subjecting each sampled aggregate to a specified number of blows from a standard-weight rammer, falling at a predefined height. AIV was calculated as the percentage of fines derived from the procedure, indicating the resistance to direct loading, offered by the aggregates.

\subsubsection{Tests for concrete workability}

3.2.2.2.1. Slump value. The workability and consistency of each fresh mix batch was assessed through a slump cone test. This test was performed following ASTM C143/C143 M [78]. While mixing each concrete batch, the slump cone was placed on a levelled surface, filled with concrete, and tamped. The cone was then lifted vertically, the slump value was computed as the difference in height between the cone and the slump sample.

\subsubsection{Tests for concrete mechanical properties}

3.2.2.3.1. Compressive strength. Compressive strength test was performed on the 7th, 14th, and 28th day of curing. The test was done on the cube-shaped concrete samples using a compression testing machine (CTM) as per ASTM C39/C39 M [67]. Samples were positioned in the CTM and the compression load was applied at the specified rate until failure occurred. The compressive strength for each mix batch was computed as a function of the recorded failure loads.

3.2.2.3.2. Split tensile strength. The split tensile strength test was performed on all mix batches on the 7th, 14th, and 28th day of curing. The test was done based on ASTM C496/C496 M [66] on the cylinder-shaped concrete samples, using a CTM. Samples were positioned horizontally in the CTM and supported above and below by steel strips along its splitting axis, the load was then applied gradually at a specified constant rate until concrete split. The split tensile strength for each concrete mix batch was computed as a function of the recorded failure loads.

\section{Results and discussions}

\subsection{Sieve analysis}

The particle size distribution illustrated in Fig. 8 indicates that the crushed seashells and granite particle sizes fell between $4.75 \mathrm{~mm}$ and $12.5 \mathrm{~mm}$, however, the curve for crushed seashells was seen to be slightly finer than that of granite. Both materials were classified as coarse aggregates following IS 2386-1:1963. Based on the unified soil classification system (USCS), using the uniformity and curvature coefficients $\left(\mathrm{C}_{\mathrm{u}}\right.$ and $\left.\mathrm{C}_{\mathrm{c}}\right)$, they were further classified as poorly-graded coarse-grained gravel. These coarse aggregates were also seen to meet the nominal aggregate size range for use as coarse aggregate in concrete indicated in Table 4. The particle size distribution curve for the river sand fell between 0.1 and $5 \mathrm{~mm}$, indicating a wider gradation. Based on IS 2386 [76] this soil was classified as fine, USCS further classifies it as well-graded sand. The fineness modulus was calculated as of 2.7, meeting the requirement indicated in Table 4. 


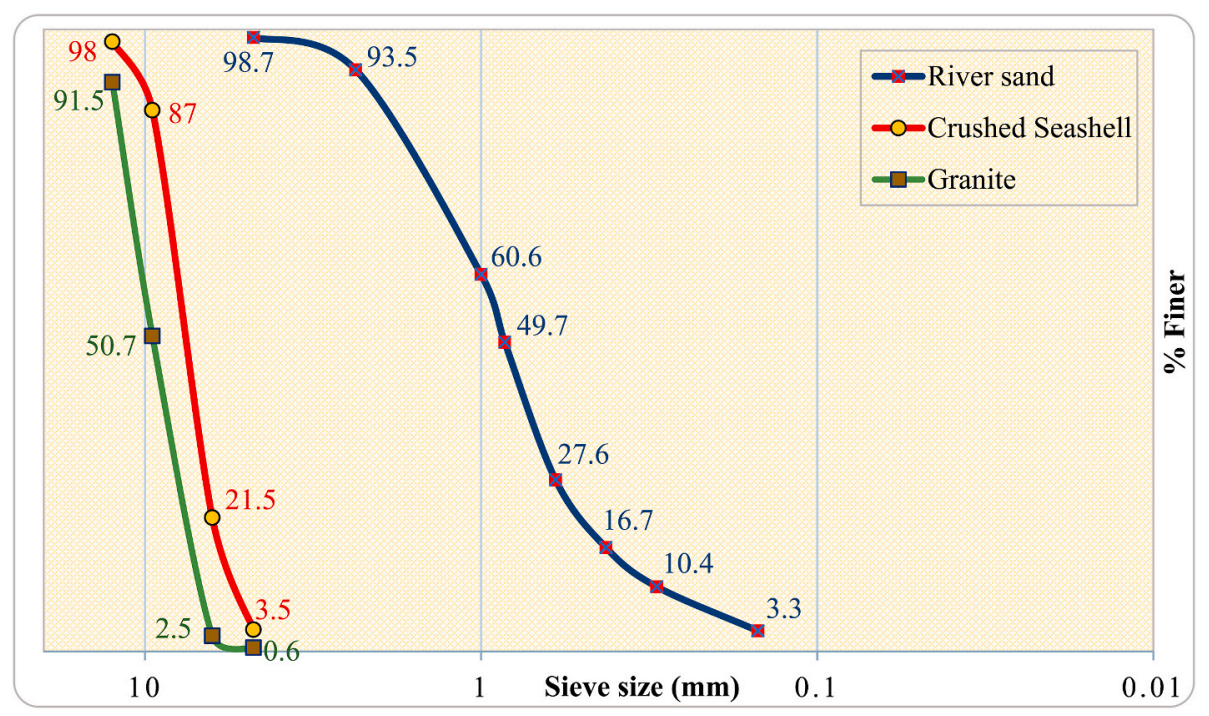

Fig. 8. Aggregate particle size distribution.

\subsection{Specific gravity $\left(S_{g}\right)$ tests}

Form the specific gravity tests, granite was found to have the highest $S_{g}$ with a value of 2.8 , followed by river sand (2.6) and crushed seashell (2.55) as shown in Table 4. The $S_{g}$ obtained by the granite, crushed seashells, and river sand all meet the standard requirements for their respective aggregate class as indicated in Table 4 . The $S_{g}$ value of the crushed seashell was seen to be similar to the value 2.50 obtained by Bharathi et al. [79].

\subsection{Water absorption tests}

Water absorption values were further computed for the coarse aggregates (granite and crushed seashells). The crushed seashells water absorption value was $1.2 \%$, which is more than twice the value of $0.5 \%$ for granite. These values indicate the porosity and resistance to freezethaw variations, higher values indicate less resistance due to high porosity. The water absorption criteria for coarse aggregates are $<2 \%$ as seen in Table 4, indicating that both materials meet the ASTM C128 [72] standard requirement. The results are presented in Table 5.

\subsection{Aggregate impact tests}

An aggregate impact value (AIV) was used to evaluate the resistance to sudden impact offered by the coarse aggregates. The AIV for granite was $26.62 \%$ while that of crushed seashell was $34.72 \%$, as shown in Table 5. The aggregate impact criteria as indicated in Table 4 is $<30 \%$ BS812 [71], signifying that the sampled crushed seashell's AIV fall beyond the allowable limit for use as coarse aggregate. However, the granite's AIV met the standard requirement.

Table 5

Specific gravity, water absorption, and aggregate impact tests results for aggregates.

\begin{tabular}{llll}
\hline Material & $\begin{array}{l}\text { Specific } \\
\text { gravity }\end{array}$ & $\begin{array}{l}\text { Water absorption } \\
(\%)\end{array}$ & $\begin{array}{l}\text { Aggregate Impact Value } \\
(\%)\end{array}$ \\
\hline $\begin{array}{l}\text { River sand } \\
\text { Crushed } \\
\text { seashell }\end{array}$ & 2.6 & - & - \\
$\begin{array}{c}\text { Granite } \\
\text { Ganite }\end{array}$ & 2.55 & 1.2 & 34.72 \\
\hline
\end{tabular}

\subsection{Slump tests}

Slump test results shown in Fig. 9 indicated a continuous decrease in workability with increasing crushed seashell percentages. However, four seashell-modified batches (SS-10, SS-20, SS-30, and SS-40) attained slump values falling within the $20 \mathrm{~mm}-50 \mathrm{~mm}$ standard slump criteria as per ASTM C143/C143 M [78]. True slumps were noticed in all mixed batches signifying that the addition of seashell does not result in concrete early-age shear or collapse. The reduction in workability can be associated with increased stiffness due to the high level of water absorption offered by the crushed seashells. The decreasing workability corresponds with results obtained from past studies utilizing different kinds of seashells $[43,48,51,53,61,64]$.

\subsection{Compressive strength tests}

The evolution of compressive strength at 7,14 , and 28 days curing stages for the different percentages of seashell replacement is shown in Fig. 10. The compressive strength continuously increased with curing age. There were also clear gradual reductions of the compressive strength as the percentages of crushed seashell increased on the 7 th, 14 th, and 28th day. On the 7th day, a reduction of about $56 \%$ was noticed in SS-50 compared to the control sample (SS-00). Both SS-10 and SS-20 achieved at least $65 \%$ of the target strength on the 7 th day, indicating recommended strength growth as per ASTM C39/C39 M [67]. the results on the 14th and 28th day indicated a similar downward trend with increasing percentages of crushed seashell.

The 28-day target strength of $25 \mathrm{~N} / \mathrm{mm}^{2}$ for M25 grade concrete was only achieved with the control mix (SS-00). The SS- 10 and SS-20 batches achieved $23.13 \mathrm{~N} / \mathrm{mm}^{2}$ and $21.48 \mathrm{~N} / \mathrm{mm}^{2}$, respectively, indicating $7.5 \%$ and $14.2 \%$, respective offsets from the target strength for M25. The reduction in compressive strength can be attributed to reasons like the high level of water absorption by the crushed seashell aggregates, the low resistance to direct impact as seen in the seashell's AIV, and the low levels of consistency observed with seashell additions in the fresh mix. Results obtained are in line with those of past studies utilizing crushed seashells as coarse aggregate replacement [52,55,58,60,62]. Only the SS-10 and SS-20 batches met the strength requirement for M20 grade concrete at 28 days, all other seashell-modified mixes did not meet standard strength requirements indicated in Table 4 based on ASTM C39/C39 M [67], and as such, are unsuitable for mass concrete production. 


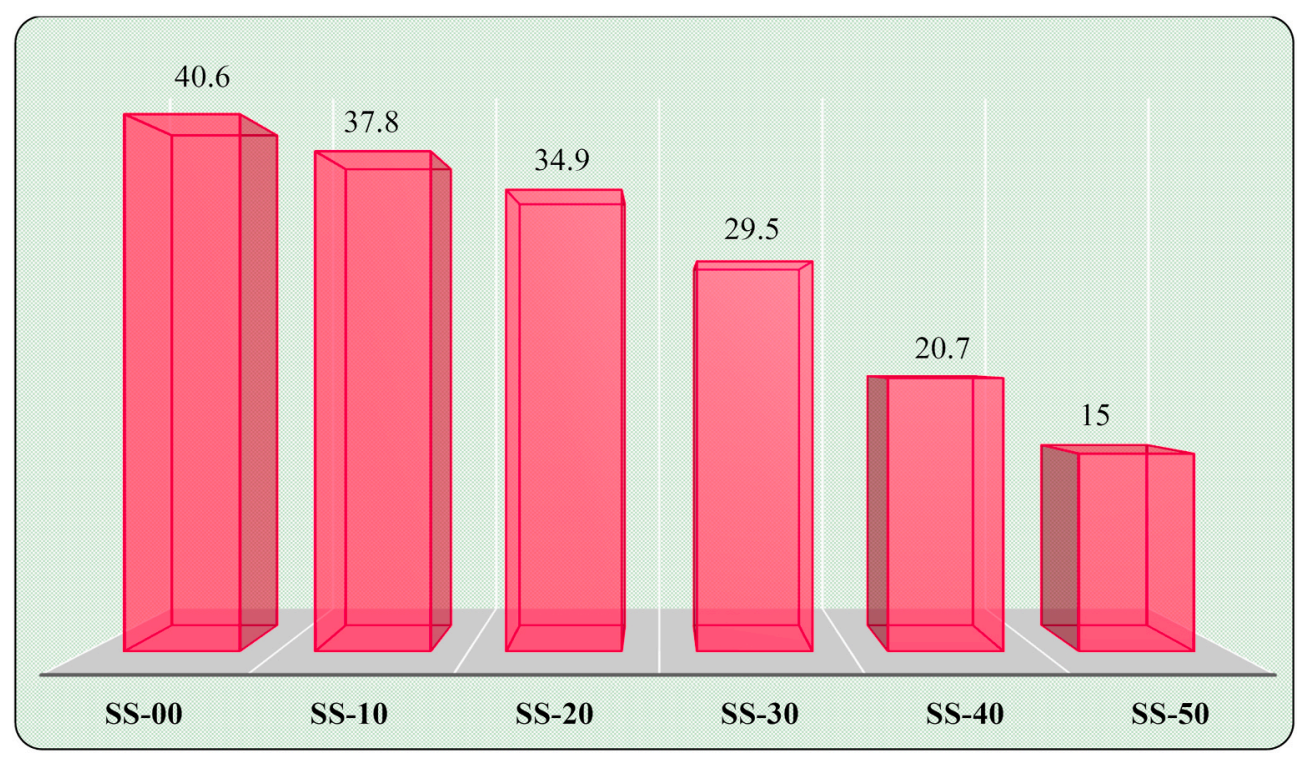

Fig. 9. Slump tests results.

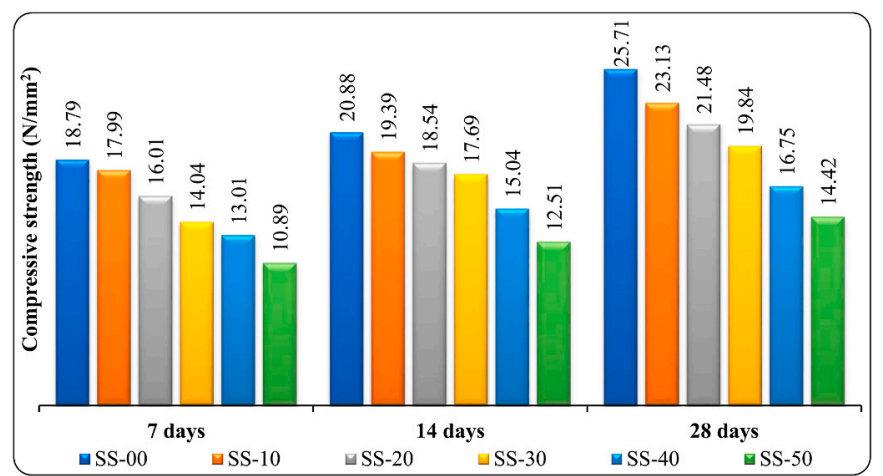

Fig. 10. Compressive strength tests results.

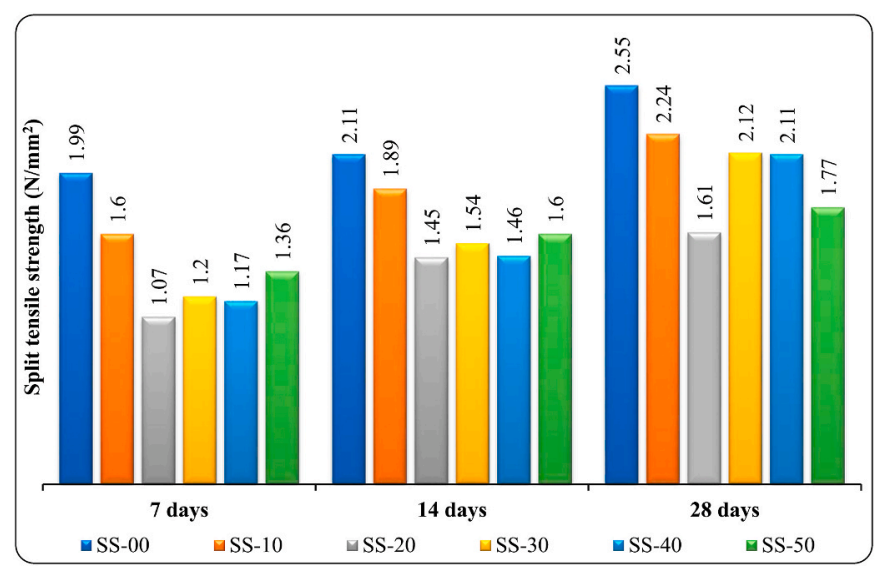

Fig. 11. Split tensile strength evaluation results.

\subsection{Split tensile strength tests}

Split tensile strength was evaluated at 7,14 , and 28 days of curing. The results obtained are presented in Fig. 11. Split tensile strength increased slightly with curing age across all mix batches. Initial tensile strength at 7 days for all seashell-modified batches were significantly lower than the unmodified batch (SS-00), the SS-20 mix yielded the lowest value, indicating a $46.2 \%$ decrease. On the 14 th and 28 th day, the split tensile strength values showed very little variations with increasing percentages of crushed seashell, a similar behaviour was noted in a study by Richardson and Fuller [60]. The SS-10 achieved the highest split tensile strength after 14 and 28 days among the seashell-modified batches, however, the tensile strength of the SS-00 mix surpassed it by $10.4 \%$ and $12.1 \%$ on the 14 th, and 28 th day, respectively.

Based on ASTM C496/C496 M [66], the SS-10, SS-30, and SS-40 achieved suitable split tensile strength values as seen in Table 4, hence, they are suitable for mass concrete production. The decrease in split tensile strength compared to conventional mix was also noticed in past studies $[52,55,58,62]$. Reasons for the slight decrease in split tensile strength were attributed to the fact that concrete's tensile strength is a function of the matrix strength, and crushed seashells particles do not significantly affect this resistance [54]. Also, it indicates the similarities in the degree of adherence to cement paste, between the crushed seashells and natural coarse aggregates. However, the increased surface area of the seashell aggregates amounts to lessened cement paste availability; hence, reduced coating and bonding strength [80]. The existence of organic matter, higher degree of water absorption, and shape properties such as flakiness or elongation offered by the seashell aggretes have also been reported to be a cause of the reduction in split tensile strength as the volume of voids in the concrete matrix increases [80]. The split tensile strength results obtained with senilia senilis seashells indicate relatively new trends with increasing percentages compared to other seashells used in past studies, and as such, further research should be done to explicate this phenomenon under different seashell-concrete applications.

Table 6

Correlation coefficients.

\begin{tabular}{|c|c|c|c|c|c|c|}
\hline \multirow[t]{2}{*}{ Variables } & \multicolumn{2}{|c|}{ Descriptive analysis } & \multicolumn{4}{|c|}{ Pearson correlation coefficient (R) } \\
\hline & Mean & Std. deviation & $\mathrm{SS}_{\%}$ & $\mathrm{~S}_{\mathrm{C}}$ & $\mathrm{S}_{\mathrm{T}}$ & $\mathrm{S}_{\mathrm{L}}$ \\
\hline $\mathrm{SS}_{\%}$ & 25.00 & 17.573 & 1 & $-0.815^{\mathrm{a}}$ & -0.483 & $-0.979^{\mathrm{a}}$ \\
\hline $\mathrm{S}_{\mathrm{C}}$ & 17.56 & 3.891 & & 1 & 0.746 & $-0.987^{\mathrm{a}}$ \\
\hline $\mathrm{S}_{\mathrm{T}}$ & 1.71 & 0.411 & & & 1 & 0.487 \\
\hline $\mathrm{S}_{\mathrm{L}}$ & 29.75 & 10.085 & & & & 1 \\
\hline
\end{tabular}

${ }^{\text {a }}$ Correlation is significant at the 0.01 level (2-tailed). 


\subsection{Statistical analysis}

\subsubsection{Correlation and regression analysis}

A bivariate Pearson correlation test was run to determine if there were relationships of any form between the values obtained for the key parameters assessed in this study which include seashell percentage, slump value, compressive strength, and split tensile strength. The descriptive and correlation analysis results are presented in Table 6 . The high value of standard deviation obtained for the seashell percentage $\left(\mathrm{SS}_{\%}\right)$ and slump $\left(\mathrm{S}_{\mathrm{L}}\right)$ variable sets are explained by the gaps in their data set.

$\mathrm{SS}_{\%}$ had very significant negative correlations with compressive strength $\left(\mathrm{S}_{\mathrm{C}}\right)$ and $\mathrm{S}_{\mathrm{L}}$, with correlation coefficient $(\mathrm{R})$ values of -0.815 and -0.979 , respectively. $S_{C}$ and $S_{L}$ were also seen to share a very significant positive correlation with an R-value of 0.987 . Split tensile strength $\left(\mathrm{S}_{\mathrm{T}}\right)$ showed significant correlation with compressive strength with an R-value of 0.746 . The correlations established from this analysis do not imply any form of cause-and-effect relationship. Nonetheless, it explains the degree of interrelations between these variables. To further assess the interdependencies, a regression analysis was conducted.

Bivariate linear regression analyses were further conducted to understand the interdependencies (cause-and-effect relationships) between the parameters assessed. The data were inspected using a box plot, and there were no outliers in the compressive strength and split tensile strength values, however, the slump values indicated two outliers at SS-40 and SS-50. The values of each criterion variable were assessed using a Shapiro-Wilk test of normality ( $p>0.05$ ), a normal distribution was observed for all three variables. There was no violation of homogeneity of variance based on Levene's equality test. The trend functions from the regression of $\mathrm{S}_{\mathrm{C}}, \mathrm{S}_{\mathrm{L}}$, and $\mathrm{S}_{\mathrm{T}}$ on $\mathrm{SS}_{\%}$ and the regression of $\mathrm{S}_{\mathrm{T}}$ on $\mathrm{S}_{\mathrm{C}}$ are presented in Fig. 12.
The linear functions developed for $\mathrm{S}_{\mathrm{C}}$ and $\mathrm{S}_{\mathrm{L}}$ with $\mathrm{SS}_{\%}$ as predictor, gave high dependence coefficients $\left(R^{2}\right)$ of 0.664 and 0.958 , respectively, indicating that the compressive strength and slump values are sufficiently explained by the seashell percentage data. The split tensile strength $\left(\mathrm{S}_{\mathrm{T}}\right)$ regression against $\mathrm{SS}_{\%}$ indicated a statistically insignificant $\mathrm{R}^{2}$-value of 0.385 using a polynomial trend function. No linear function could fit the $\mathrm{S}_{\mathrm{C}}$ data because of the insignificant $\mathrm{R}$-value indicated in Table 6 . The regression of $S_{\mathrm{T}}$ against $\mathrm{S}_{\mathrm{C}}$ also gave a linear function with an $\mathrm{R}^{2}$-value of 0.557 , indicating a significant dependence. The mathematical models developed are presented in Table 7. The models developed were further tested for validation.

\subsubsection{Model validation}

The developed models were further tested for validation. Model validation is essential because model parameters are only calibrated using available data sets. The results of the model validation test are presented in Table 8 . The test showed that the workability prediction model had the lowest error margin $(0.481 \%)$, which was expected from

Table 7

Regression analysis summary.

\begin{tabular}{|c|c|c|c|c|}
\hline Criterion & Predictor & Prediction Model & $R$ & $R^{2}$ \\
\hline Slump $\left(S_{L}\right)$ & $S S_{\%}$ & $\begin{array}{l}S_{L}=-0.5277\left(S S_{\%}\right)+ \\
42.943\end{array}$ & -0.979 & 0.958 \\
\hline $\begin{array}{l}\text { Compressive } \\
\text { strength }\left(S_{C}\right)\end{array}$ & $S S_{\%}$ & $\begin{array}{l}S_{C}=-0.1804\left(S S_{\%}\right)+ \\
22.071\end{array}$ & -0.815 & 0.664 \\
\hline $\begin{array}{l}\text { Split tensile } \\
\text { strength }\left(S_{T}\right)\end{array}$ & $S S_{\%}$ & $\begin{array}{l}S_{T}=0.0006\left(S S_{\%}\right)^{2}- \\
0.0424\left(S S_{\%}\right)+2.203\end{array}$ & 0.483 & 0.385 \\
\hline $\begin{array}{l}\text { Split tensile } \\
\quad \text { strength }\left(S_{T}\right)\end{array}$ & $S_{C}$ & $S_{T}=0.0787\left(S_{C}\right)+0.3304$ & 0.746 & 0.557 \\
\hline
\end{tabular}
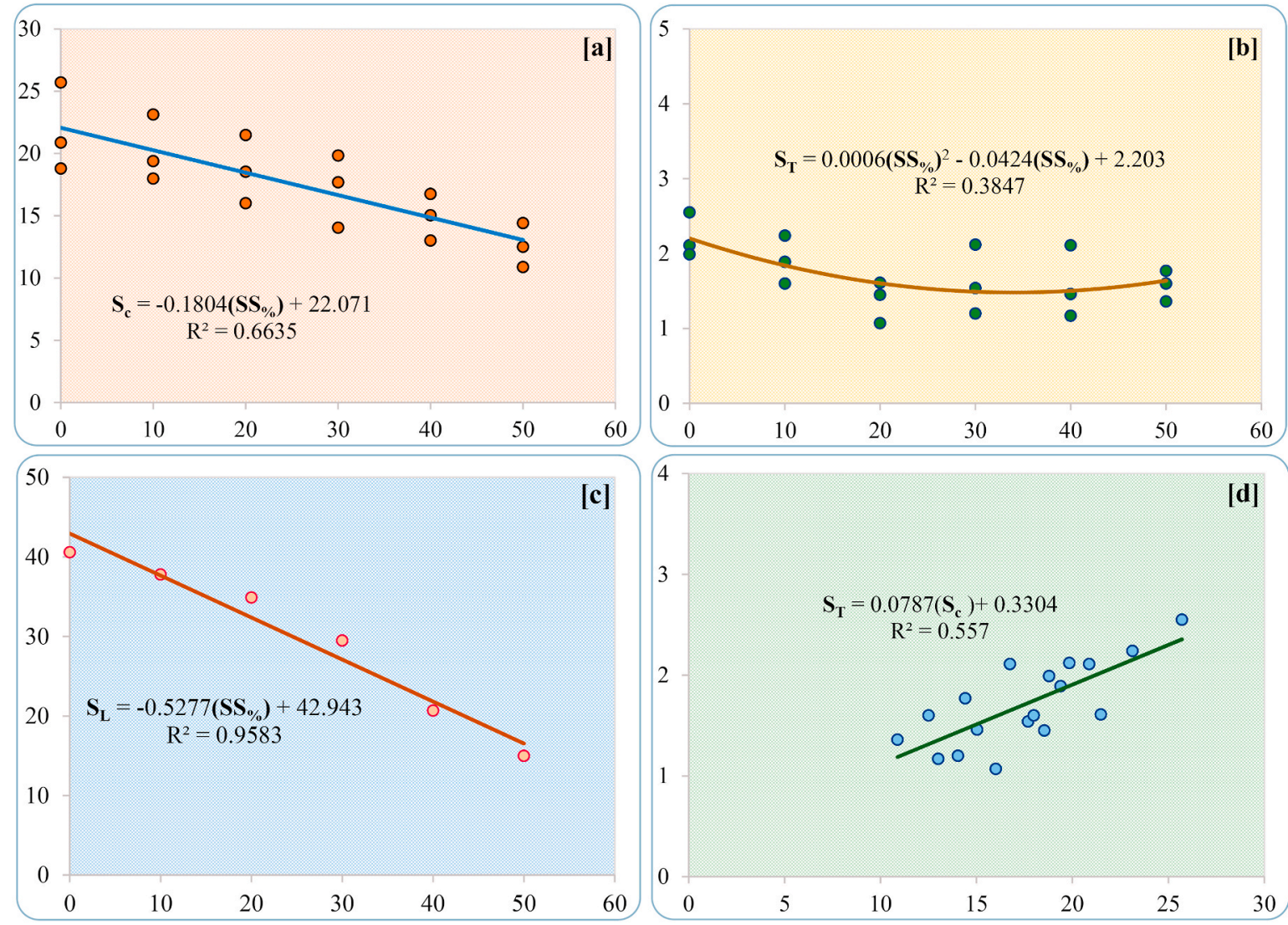

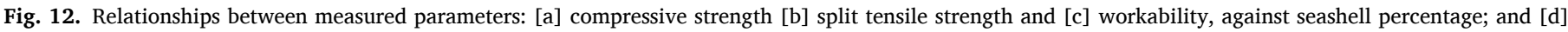
split tensile strength against compressive strength. 
Table 8

Results for Model validity tests.

\begin{tabular}{lcclc}
\hline $\begin{array}{l}\text { Predictor } \\
\text { value }(x)\end{array}$ & $\begin{array}{l}\text { Measured value } \\
\left(y_{m}\right)\end{array}$ & $\begin{array}{l}\text { Predicted value } \\
\left(y_{p}\right)\end{array}$ & $\begin{array}{l}\text { Error }\left(y_{m}-\right. \\
\left.y_{p}\right)\end{array}$ & $\begin{array}{l}\text { Mean error } \\
(\%)\end{array}$ \\
\hline \multicolumn{4}{l}{ Compressive strength/\% seashell prediction model $\left(S_{C}=-0.1804\left(S S_{\%}\right)+22.071\right)$} \\
0 & 25.71 & 22.071 & 3.639 & 1.710 \\
10 & 23.13 & 20.267 & 2.863 & \\
20 & 21.48 & 18.463 & 3.017 \\
30 & 19.84 & 16.659 & 3.181 \\
40 & 16.75 & 14.855 & 1.895 \\
50 & 14.42 & 13.051 & 1.369 \\
Split tensile strength/\% seashell prediction model $\left(S_{T}=0.0006\left(S S_{\%}\right)^{2}-\right.$ \\
$\left.0.0424\left(S S_{\%}\right)+2.203\right)$ & & & \\
0 & 2.55 & 2.203 & 0.347 & 4.140 \\
10 & 2.24 & 1.839 & 0.401 & \\
20 & 1.61 & 1.595 & 0.015 & \\
30 & 2.12 & 1.471 & 0.649 & \\
40 & 2.11 & 1.467 & 0.643 & \\
50 & 1.77 & 1.583 & 0.187 & \\
Slump/\% seashell prediction model for workability $\left(S_{L}=-0.5277\left(S S_{\%}\right)+42.943\right)$ \\
0
\end{tabular}

the high $\mathrm{R}$ and $\mathrm{R}^{2}$ values. The split tensile strength prediction models as a function of compressive strength also gave a relatively low error margin, this is as a result of the significant $\mathrm{R}^{2}$ values, the low standard error in their measurements, and the high level of fit between the linear function and the measured data. On the contrary, the split tensile strength prediction model as a function of seashell percentage gave the highest error margin. This can be as a result of the insignificant $\mathrm{R}$ and $\mathrm{R}^{2}$ values indicated, and the presence of outliers within the measured data.

In summary, based on the model calibration data, only the compressive strength and split tensile strength models are suitable for prediction within the interpolation range of the predictor variable. However, the mean error must be considered. The split tensile strength/ seashell percentage prediction model shows non-reliance and is not recommended for interpolation.

\section{Conclusion and recommendations}

This paper showcased the necessity for eco-friendly building construction in our drive towards attaining sustainability. It elucidates the concept of eco-friendly concrete production and as well revealed the reasons for its emergence, the challenges currently faced in its practical adoption, and the advantages obtainable from its application in building construction.

In addition, this research appraised the effects of recycling senilia senilis waste seashell generated in South Western Nigeria as a full or partial replacement for natural coarse aggregate in eco-friendly concrete production. The design mix constitutes a 1:2:4 concrete mix ratio for M25 grade, a w/c ratio of 0.5 , ordinary Portland cement as binder, river sand as fine aggregate, and varying proportions of crushed seashells and granite as coarse aggregates. From the Laboratory test results, the following conclusions were established: i. The workability and consistency of fresh-mix concrete reduces greatly with increasing percentages of crushed seashells. However, $10 \%-40 \%$ seashell additions give allowable slump values.

ii. The compressive strength of the concrete increased with curing age, but reduced with increasing percentages of crushed seashell at the 7 th, 14 th, and 28 th day of curing. The seashell-modified mixes failed to reach the design target strength for M25 concrete. Nonetheless, the 10 and $20 \%$ seashell-modified mixes achieved the required strength for M20 concrete.

iii. Split tensile strength increased with curing age for all mixes, the seashell-modified mixes yielded slightly lower tensile strength values compared to the unmodified mix at all curing stages, no decreasing trend was observed. The 10,30 , and $40 \%$ seashellmodified mixes attained recommended split tensile strength values.

iv. Workability and compressive strength showed high negative correlations with seashell percentage. Whereas split tensile strength only showed significant correlation with compressive strength and not with the seashell percentage data.

v. Regression analysis showed high-dependence linear functions between compressive strength, and seashell percentage with $\mathrm{R}^{2}$ of 0.6635 , and between slump values and seashell percentage with $\mathrm{R}^{2}$ of 0.9583 . Variations were established for split tensile strength, taking seashell percentage, and compressive strength separately as predictors, $\mathrm{R}^{2}$ values of 0.3847 and 0.557 , respectively, were obtained.

Lastly, to encourage the effective application of senilia senilis seashells in eco-friendly concrete production, effective waste management systems should be put in place for proper channelling of these wastes, also, active public-private stakeholder participation and support is extremely recommended in both developing and developed countries. Utilization of waste seashells could offer positive economic and environmental prospects considering the potential impacts of the removal of several million tons of waste seashells from landfills, potential material cost savings from reduced exploration of natural resources, and generation of income for seashell waste traders. Further research is recommended to extensively appraise the Life-cycle and Life-cycle-costs of this eco-friendly alternative on sustainability.

\section{CRediT authorship contribution statement}

Gideon O. Bamigboye: Conceptualization, Data curation, Investigation, Writing - review \& editing, Conception, Data curation, Investigation, Design, critical reviewing and final approval of the version submitted. Odochi Okara: Writing - original draft, Methodology, drafting of the article, Methodology. Daniel E. Bassey: Funding acquisition, Formal analysis, Design, acquisition and analysis. Kayode J. Jolayemi: Data curation, Investigation, Data curation and Investigation. David Ajimalofin: Investigation.

\section{Declaration of competing interest}

The authors declare that they have no known competing financial interests or personal relationships that could have appeared to influence the work reported in this paper.

\section{Acknowledgements}

The authors wish to thank the chancellor and the management of Covenant University for the platform made available for this research work. 


\section{References}

[1] A.O. Sojobi, S.E. Nwobodo, O.J. Aladegboye, Recycling of polyethylene terephthalate (PET) plastic bottle wastes in bituminous asphaltic concrete, Cogent Eng. 3 (1) (2016) 1-28.

[2] G.O. Bamigboye, I.I. Davies, C. Nwankwo, T. Michaels, G. Adeyemi, O. Ozuor, Innovation in construction materials - a review, in: IOP Conference Series: Materials Science and Engineering. $1^{\text {st }}$ International Conference on Sustainable Infrastructural Development (ICSID, 2019), Covenant University, Cannanland, Ota. Nigeria, 2019 June 23-28, 2019. 640 (1) 012101, 2019.

[3] D. Oakley, H. shien Tsao, Socioeconomic gains and spillover effects of geographically targeted initiatives to combat economic distress: an examination of Chicago's Empowerment Zone, Cities 24 (1) (Feb. 2007) 43-59.

[4] E. Bisung, S. Dickin, Concept mapping: engaging stakeholders to identify factors that contribute to empowerment in the water and sanitation sector in West Africa, SSM - Popul. Heal. 9 (Dec. 2019) 100490.

[5] A. Flynn, L. Yu, P. Feindt, C. Chen, Eco-cities, governance and sustainable lifestyles: the case of the Sino-Singapore Tianjin Eco-City, Habitat Int. 53 (Apr. 2016) 78-86.

[6] M. Wahlström, et al., Environmentally Sustainable Construction Products and Materials - Assessment of Release and Emissions, Oslo, 2014.

[7] L.R. de Rezende, J. Camapum de Carvalho, E.M. Palmeira, Chapter 26 the Use of Alternative and Improved Construction Materials and Geosynthetics in Pavements, vol. 3, Elsevier Geo-Engineering B. Ser., Jan. 2005, pp. 765-786. C.

[8] G.O. Bamigboye, T.A. Michaels, A.N. Ede, B.U. Ngene, U.C. Nwankwo, I. Davis, The role of construction materials in building collapse in Nigeria: a review. Journal of Physics: Conference Series, in: 3rd International Conference of Engineering for a Sustainable World (ICESW 2019) 1378, Covenant University, Cannanland, Ota. Nigeria, July , p. 042022 (4), 2019.

[9] US Environmental Protection Agency EPA, Advancing Sustainable Materials Management: 2017 Fact Sheet, 2017.

[10] C. Thiel, T. Stengel, C. Gehlen, Life cycle assessment (LCA) of road pavement materials, in: Eco-Efficient Construction and Building Materials: Life Cycle Assessment (LCA), Eco-Labelling and Case Studies, Elsevier Inc., 2013, pp. 368-403.

[11] J.Y. Park, D.E. Lee, B.S. Kim, Environmental performance analysis and economic perspectives of concrete girders, KSCE J. Civ. Eng. 23 (11) (Nov. 2019) 4592-4600.

[12] E.E. Keijzer, G.A. Leegwater, S.E. de Vos-Effting, M.S. de Wit, Carbon footprint comparison of innovative techniques in the construction and maintenance of road infrastructure in The Netherlands, Environ. Sci. Pol. 54 (2015) 218-225.

[13] G.O. Bamigoye, B.U. Ngene, O. Aladesuru, O. Mark, D. Adegoke, K.J. Jolayemi, Compressive behaviour of coconu fibre (Cocos nucifera) reinforced concrete at elevated temperatures, Fibers 8 (1) (2020) 5.

[14] M. Safiuddin, M.Z. Jumaat, M.A. Salam, M.S. Islam, R. Hashim, Utilization of solid wastes in construction materials, Int. J. Phys. Sci. 5 (13) (2010) 1952-1963.

[15] A.I. Essawy, A.M.M. Saleh, M.T. Zaky, R.K. Farag, A.A. Ragab, Environmentally friendly road construction," Egypt, J. Petrol. 22 (1) (Jun. 2013) 189-198.

[16] C.S. Vieira, P.M. Pereira, M.D.L. Lopes, Recycled Construction and Demolition Wastes as filling material for geosynthetic reinforced structures. Interface properties, J. Clean. Prod. 124 (Jun. 2016) 299-311.

[17] Z. Tang, W. Li, V.W.Y. Tam, C. Xue, Advanced progress in recycling municipal and construction solid wastes for manufacturing sustainable construction materials, Resour. Conserv. Recycl. X 6 (May 2020) 100036.

[18] E. Kissi, M. Abdulai Sadick, D.Y. Agyemang, Drivers militating against the pricing of sustainable construction materials: the Ghanaian quantity surveyors perspective, Case Stud. Constr. Mater. 8 (Jun. 2018) 507-516.

[19] J. Li, F. Xiao, L. Zhang, S.N. Amirkhanian, Life cycle assessment and life cycle cost analysis of recycled solid waste materials in highway pavement: a review, J. Clean. Prod. 233 (2019) 1182-1206.

[20] R. Jin, Q. Chen, Investigation of concrete recycling in the U.S. Construction industry, Procedia Eng. 118 (2015) 894-901.

[21] S. Khan, N. Maheshwari, G. Aglave, R. Arora, Experimental design of green concrete and assessing its suitability as a sustainable building material, Mater. Today Proc., Mar. 26 (2020) 1126-1130.

[22] J. Opon, M. Henry, An indicator framework for quantifying the sustainability of concrete materials from the perspectives of global sustainable development, J. Clean. Prod. 218 (May 2019) 718-737.

[23] L.N. Assi, K. Carter, E. Deaver, P. Ziehl, Review of availability of source materials for geopolymer/sustainable concrete, J. Clean. Prod. 263 (Aug) (2020).

[24] K.M. Rahla, R. Mateus, L. Bragança, Comparative sustainability assessment of binary blended concretes using supplementary cementitious materials (SCMs) and ordinary Portland cement (OPC), J. Clean. Prod. 220 (May 2019) 445-459.

[25] A. Wondirad, D. Tolkach, B. King, Stakeholder collaboration as a major factor for sustainable ecotourism development in developing countries, Tourism Manag. 78 (Jun) (2020).

[26] C. Lyon, et al., Five pillars for stakeholder analyses in sustainability transformations: the global case of phosphorus, Environ. Sci. Pol. 107 (May 2020) $80-89$.

[27] V.R. Vargas, R. Lawthom, A. Prowse, S. Randles, K. Tzoulas, Sustainable development stakeholder networks for organisational change in higher education institutions: a case study from the UK, J. Clean. Prod. 208 (Jan. 2019) 470-478.

[28] M.U. Hossain, C.S. Poon, I.M.C. Lo, J.C.P. Cheng, Comparative environmental evaluation of aggregate production from recycled waste materials and virgin sources by LCA, Resour. Conserv. Recycl. 109 (2016) 67-77.

[29] T.Y. Tu, Y.Y. Chen, C.L. Hwang, Properties of HPC with recycled aggregates, Cement Concr. Res. 36 (2006) 943-950.
[30] L.W. Zhang, A.O. Sojobi, K.M. Liew, Sustainable CFRP-reinforced recycled concrete for cleaner eco-friendly construction, J. Clean. Prod. 233 (Oct. 2019) 56-75.

[31] R.S. Atea, A case study on concrete column strength improvement with different steel fibers and polypropylene fibers, J. Mater. Res. Technol. 8 (6) (Nov. 2019) 6106-6114.

[32] Food and Agriculture Organization of the United Nations FAO, The State of the World Fisheries and Aquaculture, 2016. Rome.

[33] I.F.A.D. FAO, W.F.P. UNICEF, WHO, The State of Food Security and Nutrition in the World, 2018. Rome.

[34] Food and Agriculture Organization of the United Nations FAO, Global aquaculture production, FAO Fish. Stat. Collect. (2015) 1-227. October.

[35] Food and Agriculture Organization of the United Nations FAO, The State of the World Fisheries and Aquaculture, 2014.

[36] M. Tokeshi, N. Ota, T. Kawai, A comparative study of morphometry in shellbearing molluscs, J. Zool. 251 (1) (May 2000) 31-38.

[37] J.P. Morris, T. Backeljau, G. Chapelle, Shells from aquaculture: a valuable biomaterial, not a nuisance waste product, Rev. Aquacult. 11 (1) (2019) 42-57.

[38] T.H. Silva, J. Mesquita-Guimarães, B. Henriques, F.S. Silva, M.C. Fredel, The potential use of oyster shell waste in new value-added by-product, Resources 8 (1) (2019) 1-15.

[39] A. FitzGerald, Shell Waste in Aggregates, 2017.

[40] A.A. Jimoh, I.P. Lemomu, Shellfish Resources in Nigeria, 2010.

[41] A. Alabi, Developing Shellfish Industry in Nigeria :Technology and Economics, 2010 .

[42] I.C. Attah, R.K. Etim, J.E. Sani, Response of oyster shell ash blended cement concrete in sulphuric acid environment, Civ. Environ. Res. 11 (2) (2019) 8-26.

[43] A.E. Inyang, B.R. Etuk, The effect of calcination temperature on the chemical composition of oyster, periwinkle and snail shell ash, Int. J. Res. Eng. Technol. (2016) 200-203, vol. 05, no. 08.

[44] A.A. Umoh, A.O. Ujene, Improving the strength performance of high volume periwinkle shell ash blended cement concrete with sodium nitrate as accelerator, J. Civ. Eng. Sci. Technol. 6 (2) (Sep. 2015) 18-22.

[45] Food and Agriculture Organization of the United Nations FAO, Fishery and Aquaculture Country Profiles - the Federal Republic of Nigeria, 2019 [Online] Available: http://www.fao.org/fishery/facp/NGA/en [Accessed: 14-May-2020].

[46] R. Lavaud, J. Thébault, A. Lorrain, M. van der Geest, L. Chauvaud, Senilia senilis (Linnaeus, 1758), a biogenic archive of environmental conditions on the Banc d'Arguin (Mauritania), J. Sea Res. 76 (Feb. 2013) 61-72.

[47] E. Gosling, Bivalve Molluscs: Biology, Ecology and Culture, Blackwell Publishing, 2003.

[48] M. Olivia, R. Oktaviani, Ismeddiyanto, Properties of concrete containing ground waste cockle and clam seashells, Procedia Eng. 171 (2017) 658-663.

[49] B.A. Tayeh, et al., Durability and mechanical properties of seashell partiallyreplaced cement, J. Build. Eng. 31 (Sep. 2020) 101328.

[50] V. Mohanalakshmi, S. Indhu, P. Hema, V.C. Prabha, Developing concrete using sea shell as a fine aggregate, IJIRST -International J. Innov. Res. Sci. Technol. 3 (10) (2017) 282-286.

[51] C. Varhen, S. Carrillo, G. Ruiz, Experimental investigation of Peruvian scallop used as fine aggregate in concrete, Construct. Build. Mater. 136 (2017) 533-540.

[52] C. Martínez-García, B. González-Fonteboa, F. Martínez-Abella, D. Carro- López, Performance of mussel shell as aggregate in plain concrete, Construct. Build. Mater. 139 (2017) 570-583.

[53] B.A. Tayeh, M.W. Hasaniyah, A.M. Zeyad, M.O. Yusuf, Properties of concrete containing recycled seashells as cement partial replacement: a review, J. Clean. Prod. 237 (10-Nov-2019) 117723. Elsevier Ltd.

[54] B. Safi, M. Saidi, A. Daoui, A. Bellal, A. Mechekak, K. Toumi, The use of seashells as a fine aggregate (by sand substitution) in self-compacting mortar (SCM)," Constr, Build. Mater. 78 (Mar. 2015) 430-438.

[55] T. Soneye, A.N. Ede, G.O. Bamigboye, D.O. Olukanni, The study of periwinkle shells as fine and coarse aggregate in concrete works, in: 3rd Int. Conf. African Dev. Issues (CU-ICADI 2016), 2016, pp. 361-364. May.

[56] M. Olivia, A.A. Mifshella, L. Darmayanti, Mechanical properties of seashell concrete, Procedia Engineering 125 (2015) 760-764.

[57] H. G, C. Nahushananda, T. Mutusva, Investigation of properties of concrete with seashells as a coarse aggregate replacement in concrete, MATTER Int. J. Sci. Technol. 1 (1) (Jan. 2015) 285-295.

[58] P.S. Kumar, C.S. Kumar, P. Yuvaraj, B.M. Kumar, E.K.J. Mohan, A partial replacement for coarse aggregate by sea shell and cement by lime in concrete 2 (5) (2016) 1131-1136, 2016.

[59] A.W. Otunyo, I.U. Friday, T.A. Israel, Exploratory study of crushed coconut shell as partial replacement for fine aggregates in concrete, J. Emerg. Trends Eng. Appl. Sci. 4 (6) (2013) 823-827.

[60] A.E. Richardson, T. Fuller, Sea shells used as partial aggregate replacement in concrete, Struct. Surv. 31 (5) (2013) 347-354.

[61] O. Norhazurina, B. Abubakar, M. Megatjohari, M. Matdon, Potential use of cockle ( anadara granosa ) shell ash as partial cement replacement in concrete, Casp. J. Appl. Sci. Res. 2 (2013) 369-376. AICCE'12 \& GIZ' 12.

[62] D.H. Nguyen, M. Boutouil, N. Sebaibi, F. Baraud, L. Leleyter, Durability of pervious concrete using crushed seashells, Construct. Build. Mater. 135 (2017) 137-150.

[63] S. Abinaya, S.D.P. Venkatesh, An effect on oyster shell powder's mechanical properties in self compacting concrete, Int. J. Innov. Res. Sci. Eng. Technol. 5 (6) (2016).

[64] P. Lertwattanaruk, N. Makul, C. Siripattarapravat, Utilization of ground waste seashells in cement mortars for masonry and plastering, J. Environ. Manag. 111 (2012) 133-141. 
[65] B. Wang, J.Q. Chu, Y.M. Song, Study on preparation and performance of shellbased ecological composite white cement, J. Build. Mater. 15 (5) (Oct. 2012).

[66] ASTM C496/C496M-17, Standard Test Method For Splitting Tensile Strength Of Cylindrical Concrete Specimens, 2017.

[67] ASTM C39/C39M-20, Standard Test Method for Compressive Strength of Cylindrical Concrete Specimens, 2020.

[68] ASTM C33/C33M-18, Standard Specification For Concrete Aggregates, 2018.

[69] ASTM C127, ASTM C127 Standard Test Method for Density, Relative Density (Specific Gravity ), and Absorption,", ASTM Standard Book, West Conshohocken, PA, 2015, pp. 1-6.

[70] ASTM C88/C88M-18, Standard Test Method for Soundness of Aggregates by Use of Sodium Sulfate or Magnesium Sulfate, 2018.

[71] British Standards Institution BSI, BS 812: Testing Aggregates-Part 112: Methods for Determination of Aggregate Impact Value (AIV), British Standards Institution, 1990.

[72] ASTM C131/C131M-20, Standard Test Method For Resistance To Degradation Of Small-Size Coarse Aggregate by Abrasion and Impact in the Los Angeles Machine, 2020.
[73] ASTM C128-15, Standard Test Method for Relative Density (Specific Gravity) and Absorption of Fine Aggregate, 2015.

[74] ASTM C138/C138M-17a, Standard Test Method for Density (Unit Weight), Yield, and Air Content (Gravimetric) of Concrete, 2017.

[75] ASTM C293/C293M-16, Standard Test Method for Flexural Strength of Concrete (Using Simple Beam with Center-Point Loading), 2016.

[76] IS 2386 part.I:1963, "Methods of Test for Aggregates for Concrete Part I Particle Size and Shape, 2007.

[77] ASTM D1429-13, Standard Test Methods for Specific Gravity of Water and Brine, 2013. West Conshohocken, PA.

[78] ASTM C143/C143M-15a, Standard Test Method for Slump of Hydraulic-Cement Concrete, 2015, pp. 1-4. West Conshohocken, PA.

[79] R.Y. Bharathi, S. Subhashini, T. Manvitha, S.H. Lessly, Experimental study on partial replacement of coarse aggregate by seashell \& partial replacement of cement by flyash, Int. J. Eng. Res. 5 (11) (2016).

[80] U.G. Eziefula, J.C. Ezeh, B.I. Eziefula, Properties of seashell aggregate concrete: a review, Construct. Build. Mater. 192 (20-Dec-2018) 287-300. Elsevier Ltd. 